УДК 378.046.4. (044)

DOI: 10.37026/2520-6427-2021-107-3-48-53
Микола СОЛОВЕЙ,

кандидат педагогічних наук, доиент, декан факультету підвищення кваліфікаиії Хмельницького обласного інституту післядипломної педагогічної освіти, м. Хмельницький, Україна ORCID: 0000-0001-5520-7111 e-mail:nikolosolovey@gmail.com

\title{
ПІДВИЩЕННЯ КВАЛІФІКАЦЇ̈ ПЕДАГОГІЧНИХ ПРАЦІВНИКІВ ЗАКЛАДІВ ПОВНОЇ ЗАГАЛЬНОЇ СЕРЕДНЬОЇ ОСВІТИ В СУЧАСНИХ УМОВАХ: ОРГАНІЗАЦІЙНИЙ АСПЕКТ
}

\begin{abstract}
Анотація. У статті на основі дослідження сучасних нормативно-правових документів, теорії $i$ практики підвищення кваліфікації педагогічних працівників визначено та описано особливості організаціі ицього процесу в умовах вільного вибору і становлення альтернативних суб'єктів післядипломної освіти. Нами виокремлено інноваційні елементи, що мають суттєве значення в управлінні підвищенням кваліфікаиії педагогічних працівників закладів повної загальноі середньої освіти, виділено завдання та покрокові діi вчителя і керівника в річному управлінському ииклі.

Суть проиесу проявлясться у рефлексії педагогом особистого рівня професійного розвитку, виборі суб 'єкта, освітньої програми, форми і виду підвищення кваліфікації. В адмініструванні виокремлюємо прочееури планування, проведення педагогічної ради,
\end{abstract}

складання й затвердження плану, розробки інструментарію (наказів, положень, договорів, тощо) і визнання результатів підвищення кваліфікаиї̈. Визнання розглядаємо як колективну дію, спрямовану на встановлення відповідності документів про підвищення кваліфікації нормативним вимогам прийняття відповідного протоколу у формі рішення педагогічної ради. У загальному контексті пропонуємо ідею про внутрішнє положення щзодо визнання результатів підвищення кваліфікації, головним у якій є принцип законності. У нашому дослідженні ми вперше виділяємо загальні аспекти визнання, конкретне їх виявлення за основними формами підвищення кваліфікації.

Ключові слова: підвищення кваліфікації, річний циикл, самоаналіз, планування, оплата послуг, визнання.

Mykola SOLOVEY,

Candidate of Pedagogical Sciences,

Associate Professor, Dean of the Faculty of

Khmelnytsky Regional Institute

of Postgraduate Pedagogical Education,

Khmelnytsky, Ukraine

ORCID: 0000-0001-5520-7111

e-mail: nikolosolovey@gmail.com

\section{THE ORGANIZATION OF ADVANCED TRAINING OF PEDAGOGICAL WORKERS OF ESTABLISHMENTS OF FULL GENERAL SECONDARY EDUCATION IN MODERN CONDITIONS}

\begin{abstract}
The article describes the results of a study of modern legal documents on professional development of teachers. According to Article 27 of the Law of Ukraine «On Education» (2017), advanced training becomes annu$a l$, and the total number of academic hours is fixed and for employees of general secondary education can not be less than 150 hours. for five years. The law paves the way for the accumulation of formal, non-formal and informal education for five years. At the same time, it fixes the right to advanced
\end{abstract}

training in educational institutions that have the appropriate license or conduct educational activities under an accredited programme. This rule was further developed in Art. 51 of the Law of Ukraine "On complete general secondary education (2020), which guarantees the right to advanced training, primarily in the municipal institution of in-service pedagogical education located on the territory of residence, as well as in other educational institutions and entities that declare the possibility of such educational activities. 
Under the conditions of the autonomy of the educational institution, the tasks of the pedagogical council change. In recognizes the results and distributes funds for advanced training.

In the practice of school management, we identify new tasks for the management of professional development of teachers. We have modeled and proposed a step-by-step cycle of actions (tasks) of a teacher and the head of an educational institution in the conditions of free choice and formation of alternative subjects of in-service education. Their essence is manifested in the reflection of the teacher's personal level of professional development, the choice of subject, educational program, form and type of training. In the administration of this process, we distinguish the procedure of planning, conducting the pedagogical council, drawing up and approving the plan of the professional development, tool development (orders, regulations, instructions, etc.) and recognition of the results of the professional development. Based on the study of legal documents and guidelines of the Ministry of Education and Science of Ukraine, we highlight the general aspects of the recognition procedure and their specific identification according to the main forms of training.

Key words: advanced training, annual cycle, introspection, planning, payment for services recognition procedure.

Постановка проблеми Сучасні Закони України «Про освіту» (2017) (далі - Закон), «Про повну загальну середню освіту» (2020) (далі - Закон ПЗСО) унормовують концептуальні засади підвищення кваліфікації педагогічних працівників (далі - ПКПП). Постанова Кабінету Міністрів України від 21.08.2019 р. № 800 «Деякі питання підвищення кваліфікації педагогічних і науково-педагогічних працівників» окреслює механізми організації цього процесу.

Наразі створені законодавчо-нормативні передумови для розвитку різних моделей ПКПП (полісуб'єктних, диверсифікованих), у яких учитель обирає, педагогічна рада затверджує і спрямовує, а суб'єкти освітньої діяльності надають послугу відповідно до особистісного вибору педагогічного працівника.

Водночас з'являється необхідність переосмислення організаційних складових управління підвищенням кваліфікації в закладах освіти.

Аналіз наукових досліджень і публікацій. Проблеми професійного розвитку і підвищення кваліфікації педагогічних працівників у контексті післядипломної освіти досліджуються у численних наукових розвідках, зокрема крізь призму місії післядипломної освіти в умовах трансформації сучасного суспільства (Олійник, 2013), у контексті андрагогічного, акмеологічного і компетентнісного підходів в освіті дорослих (Мірошник, 2016), глобалізації і зарубіжного досвіду (Лунячек, 2017), диверсифікації підвищення кваліфікації (Олефіра, 2017) та інші.

Досліджуючи сучасні моделі професійного розвитку вчителя, I. П. Воротнікова (2018) описує прикладну (Applied Science), ремісничу (Craft Model) i рефлексивну (Reflective Model) моделі й підходи, які склалися у світовій практиці.
Отже, з точки зору сучасних теоретичних засад, підвищення кваліфікації можна здійснювати за різними моделями і формами, організовувати його на основі системності, неперервності за накопичувальною системою (Осадчий, 2016).

Водночас за будь-яких обставин учитель на основі рефлексії знань різних сфер науки і культури та власної практики має особисто приймати рішення про найоптимальніші для нього форми й види підвищення кваліфікації. Це зафіксовано у сучасному законодавстві про освіту. Отже, на зміну традиційній, запроваджується модель підвищення кваліфікації, коли учитель обирає, педагогічна рада затверджує, керівник спрямовує, а суб' єкти освітньої діяльності надають послугу відповідно до укладених угод. У зв'язку 3 цим центр організації ПКПП зміщується з інститутів післядипломної освіти у заклади освіти. Таким чином, організація ПКПП як інноваційний об'єкт управлінської діяльності керівника, на нашу думку, потребує дослідження та визначення на рівні його складових.

Мета статті спрямована на визначення складових організації та управління підвищенням кваліфікації педагогічних працівників у закладі повної загальної середньої освіти в сучасних умовах.

Виклад основного матеріалу дослідження. За результатами аналізу Закону України «Про освіту» (2017), Постанови Кабінету Міністрів України (2019) встановлено, що в умовах становлення Нової української школи змінюються нормативні засади ПКПП, що вказує на зміни в їх організації, в контексті яких учитель набуває права обирати форми і види освітніх послуг, а держава гарантує їх фінансування.

У нових умовах ПКПП набуває ознак фіксованого, системного процесу, відповідно до статті 27 Закону (2017), для педагогічних працівників закладів повної загальної середньої освіти стає щорічним, а загальна кількість академічних годин є фіксованою і не може бути меншою за 150 год впродовж п'яти років. Законодавчо-нормативні документи сприяють накопиченню сукупних результатів формальної, неформальної та інформальної освіти упродовж п'яти років. Водночас вони фіксують право на підвищення кваліфікації у суб'єктів освіти, що мають відповідну ліцензію або проводять освітню діяльність за акредитованою програмою. Ця норма набула подальшого розвитку в ст. 51 Закону ПЗСО (2020), в якій гарантовано право підвищувати кваліфікацію насамперед у комунальному закладі післядипломної педагогічної освіти, розташованому на території за місцем проживання, а також в інших навчальних закладах і суб'єктів, що декларують можливість проведення подібної освітньої діяльності.

Закон (2017) прописує зміни порядку фінансування підвищення кваліфікації, в якому ст. 78 п. 8 передбачено, що на підвищення кваліфікації додатково має спрямовуватися не менше $2 \%$ коштів від фонду заробітної плати. У нових умовах кошти на підвищення кваліфікації закладаються в закладі освіти і відповідно до кошторису спрямовуються за цільовим призначенням.

Інноваційним $є$ й те, що за цієї умови змінюються завдання педагогічної ради, яка відповідно до Закону (2017), на основі пропозицій педагогічних працівників, 
затверджує план (ст. 59 п.3), визнає результати і розподіляє кошти на підвищення кваліфікації (ст. 59 п.5).

Отже, сучасні зміни в освіті, їх нормативне упорядкування виокремлюють нові завдання керівника щодо організації та ефективного управління підвищенням кваліфікації педагогічних працівників закладів повної загальної середньої освіти. Вчитель відтепер зобов'язаний здійснювати певні дії щодо аналізу інформації про форми, види й умови надання освітніх послуг, вибирати суб'єкт освітньої діяльності, вносити пропозиції на розгляд педагогічної ради, а керівник закладу - складати план ПКПП і кошторис, укладати договори, організовувати роботу педагогічної ради з ухвали рішення про визнання результатів підвищення кваліфікації тощо.

В організаційному контексті ми розглядаємо це як упорядковану діяльність із метою створення оптимальних умов професійного розвитку на основі свободи вибору й адміністративного керівництва процесом як складової управління закладом освіти.

На основі вивчення сучасних законодавчо-нормативних документів, теорії і практики підвищення кваліфікації ми розробили покроковий цикл дій учителя і керівника закладу освіти щодо організації підвищення кваліфікації педагогічних працівників у нових умовах. Оскільки відповідно до Закону (2017) педагогічний працівник закладу загальної середньої освіти підвищує кваліфікацію щорічно, то ці завдання, на нашу думку, доцільно розв'язувати в річному управлінському циклі як системному процесі, що має особистісне й адміністративне виявлення (див. табл. 1). Доцільно встановлювати терміни виконання основних дій, але оскільки вони (терміни) відрізнятимуться у кожному конкретному закладі, залишаємо це питання на розгляд керівника.
Вибір програм і суб'єктів підвищення кваліфікації - це перший крок у загальному алгоритмі дій, що дає можливість внести пропозиції про види, форми, програми підвищення кваліфікації. Свобода вибору в означеному контексті забезпечується самоаналізом власної практики і педагогічного досвіду, що поєднується із самооцінкою, визначенням пріоритетів і перспектив професійного розвитку, програм і суб'єктів освітньої діяльності. Водночас зауважимо, що при виборі суб'єктів надання освітньої програми, на нашу думку, доцільно враховувати їх легітимність (наявність відповідних ліцензій, акредитованих програм, окремих дозволів на проведення освітньої діяльності чи, можливо, договорів про спільну діяльність на засадах кооперації).

Важливою складовою циклу є планування ПКПП, що й передбачено ст. 8 п.5 Закону і постановою Кабінету Міністрів України від 21.08.2019 р. № 800. Заклад освіти - складна соціально-діяльнісна система відносин і комунікацій, тому процес планування розглядаємо як дію, спрямовану на узгодження та узагальнення пропозицій, напрямів, суб'єктів і часу підвищення кваліфікації педагогічного працівника відповідно до загальних цілей, можливостей ресурсного і фінансового забезпечення. Форма плану як документа подана у рекомендаціях Мiністерства освіти і науки України (2021). Водночас вона може бути адаптована (змінена) до конкретних умов.

Непростими є дії щодо фінансування та оплати послуг із підвищення кваліфікації відповідно до кошторису закладу освіти, як це передбачено Законом (2017). Найсуттєвішим викликом у розв'язанні означеного завдання $є$ те, що наразі заклади освіти як фінансово самостійні установи перебувають у стані становлення, а бюджетування підвищення кваліфікації поки що триває за принципом централізованої моделі.

Таблиия 1

Оріснтовний цикл організації підвищення кваліфікації (алгоритм дій для керівника)

\begin{tabular}{|c|c|c|c|}
\hline Зміст дії & Виконавець & Форма рішення & Документ \\
\hline \multicolumn{4}{|c|}{ Крок 1. Вибір програм і суб'єктів освітньої діяльності } \\
\hline $\begin{array}{l}\text { Самоаналіз. Аналіз інформації про фор- } \\
\text { ми, види та умови надання освітніх по- } \\
\text { слуг різними суб'єктами освітньої діяль- } \\
\text { ності, подання пропозицій до розгляду } \\
\text { на педагогічній раді щодо проходження } \\
\text { підвищення кваліфікації }\end{array}$ & педагогічні працівники & $\begin{array}{l}\text { індивідуальне рішення } \\
\text { педагога про вибір }\end{array}$ & $\begin{array}{l}\text { пропозиція } \\
\text { для розгляду на педа- } \\
\text { гогічній раді у довіль- } \\
\text { ній формі }\end{array}$ \\
\hline \multicolumn{4}{|c|}{ Крок 2. Планування підвищення кваліфікації } \\
\hline $\begin{array}{l}\text { Прийняття пропозицій та їх } \\
\text { систематизація. } \\
\text { Підготовка рішення педагогічної ради }\end{array}$ & $\begin{array}{l}\text { відповідальний за пла- } \\
\text { нування та організацію } \\
\text { підвищення кваліфікації }\end{array}$ & $\begin{array}{l}\text { узагальнені } \\
\text { пропозиції; проєкт рішен- } \\
\text { ня педагогічної ради }\end{array}$ & $\begin{array}{l}\text { рішення педагогічної } \\
\text { ради }\end{array}$ \\
\hline \multicolumn{4}{|c|}{ Крок 3. Оплата послуг підвищення кваліфікації } \\
\hline $\begin{array}{l}\text { Розробка проєкту кошторису і формуван- } \\
\text { ня бюджстного запиту; оприлюднення } \\
\text { кошторису, коригування плану ПК, укла- } \\
\text { дання договорів про підвищення квалі- } \\
\text { фікації, опрацювання рахунків і переказ } \\
\text { коштів за надання освітньої послуги }\end{array}$ & $\begin{array}{l}\text { керівник, } \\
\text { бухгалтер }\end{array}$ & $\begin{array}{l}\text { бюджетний запит, } \\
\text { кошторис }\end{array}$ & $\begin{array}{l}\text { рішення педагогічної } \\
\text { ради про план ПК і } \\
\text { розподіл коштів; дого- } \\
\text { вір, інші документи }\end{array}$ \\
\hline \multicolumn{4}{|c|}{ Крок 4. Визнання результатів підвищення кваліфікації } \\
\hline $\begin{array}{l}\text { Встановлення відповідності документів } \\
\text { про підвищення кваліфікації до норма- } \\
\text { тивних вимог }\end{array}$ & $\begin{array}{l}\text { керівник, } \\
\text { відповідальний за пла- } \\
\text { нування і організацію } \\
\text { підвищення кваліфікації }\end{array}$ & $\begin{array}{l}\text { рішення педагогічної } \\
\text { ради }\end{array}$ & $\begin{array}{l}\text { рішення педагогічної } \\
\text { ради }\end{array}$ \\
\hline
\end{tabular}


За умови передачі бюджету на підвищення кваліфікації в заклади освіти в організаційному забезпеченні цього кроку необхідною складовою, на нашу думку, є: формування бюджетного запиту (проєкту кошторису) на основі попереднього плану ПКПП, корегування плану ПКПП, виходячи з наявного фінансування та 3 урахуванням лімітних довідок, підготовка й ухвалення відповідного рішення педагогічної ради, укладання договорів із суб' єктами надання освітніх послуг, підготовка наказів про ПКПП та іншого інструментарію, пов'язаного з менеджментом цього процесу тощо.

В умовах становлення автономії закладу повної загальної середньої освіти зростає роль педагогічної ради, яка відповідно до постанови Кабінету Міністрів України (2019) схвалює план, кошторис і ухвалює рішення про визнання ПКПП.

Визнання результатів підвищення кваліфікації завершальний крок управлінського циклу. Ми розглядаємо його як процедуру встановлення відповідності документів про підвищення кваліфікації нормативним вимогам. Складність полягає в тому, що наразі не- має стандарту підвищення кваліфікації педагогічних працівників. До уваги можемо брати ст.12 Закону (2017), напрями підвищення кваліфікації, визначені постановою Кабінету Міністрів України (2019), професійний стандарт учителя закладу загальної середньої освіти і вчителя початкових класів (2020) тощо. На основі дослідження сучасних нормативно-правових документів і методичних рекомендацій Міністерства освіти і науки України виокремлюємо загальні аспекти цього процесу і конкретне виявлення за основними формами підвищення кваліфікації (див. табл. 2, 3).

Рішення про визнання (невизнання) ухвалює педагогічна рада на основі відповідних заяв та документів про підвищення кваліфікації, які подає педагогічний працівник. На нашу думку, педагогічна рада повинна керуватися внутрішнім положенням про визнання результатів підвищення кваліфікації, у якому доцільно прописати основні засади і принципи визнання, головним з яких є принцип законності, що враховує вимоги Закону (2017), Закону ПЗСО (2020) і перерахованих вище нормативних документів.

Таблиця 2

Загальні аспекти визнання результатів підвищення кваліфікації за основними формами

\begin{tabular}{|c|l|l|l|}
\hline \multicolumn{1}{|c|}{ Форми } & \multicolumn{1}{|c|}{ Коротка характеристика } & \multicolumn{1}{|c|}{ Пидстава для визнання } \\
\hline Формальна & $\begin{array}{l}\text { передбачає досягнення } \\
\text { визначених рівнів } \\
\text { і стандартів }\end{array}$ & $\begin{array}{l}\text { освітні програми; } \\
\text { семінари, практикуми, тренінги } \\
\text { тощо у закладах післядипломної } \\
\text { освіти, університетах }\end{array}$ & $\begin{array}{l}\text { ліцензія, } \\
\text { акредитація }\end{array}$ \\
\hline Неформальна & $\begin{array}{l}\text { програма не передбачає } \\
\text { досягнення визнаних } \\
\text { державою рівнів } \\
\text { кваліфікації }\end{array}$ & $\begin{array}{l}\text { освітні програми, тренінги тощо у } \\
\text { субктів освітньої діяльності, } \\
\text { у статутах яких передбачені } \\
\text { освітні послуги }\end{array}$ & $\begin{array}{l}\text { рішення педагогічної } \\
\text { ради }\end{array}$ \\
\hline Інформальна & $\begin{array}{l}\text { самоорганізоване здобуття } \\
\text { певних компетентностей }\end{array}$ & $\begin{array}{l}\text { дамоосвіта у повсякденній } \\
\text { дішенті } \\
\text { ради }\end{array}$ \\
\hline
\end{tabular}

Таблиия 3

Конкретизація визнання результатів підвищення кваліфікації за основними формами і видами

\begin{tabular}{|c|c|c|c|c|}
\hline Форми & Види & Тривалість & Суб’єкт & Визнання \\
\hline \multicolumn{5}{|c|}{ Формальна освіта } \\
\hline \multirow{3}{*}{ 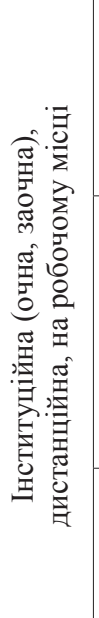 } & $\begin{array}{l}\text { навчання за освітніми програми, зокрема } \\
\text { участь у семінарах, практикумах тренінгах, } \\
\text { вебінарах, майстер-класах тощо. } \\
\text { Стажування }\end{array}$ & $\begin{array}{l}\text { визначає суб’єкт } \\
\text { освітньої діяльності }\end{array}$ & \multirow{3}{*}{ 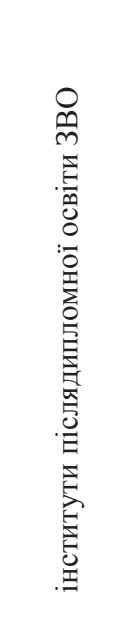 } & $\begin{array}{l}\text { не потребують } \\
\text { рішення про визнання }\end{array}$ \\
\hline & $\begin{array}{l}\text { здобуття першого (бакалаврського), другого } \\
\text { (магістерського) рівнів вищої освіти }\end{array}$ & \multirow{2}{*}{$\begin{array}{l}\text { відповідно до обсягу } \\
\text { освітньо-професійної } \\
\text { програми }\end{array}$} & & \multirow[t]{2}{*}{$\begin{array}{l}\text { рішенням } \\
\text { педагогічної ради }\end{array}$} \\
\hline & $\begin{array}{l}\text { здобуття третього (освітньо-наукового) або } \\
\text { наукового рівня вищої освіти }\end{array}$ & & & \\
\hline
\end{tabular}


Продовження табл. 3

\begin{tabular}{|c|c|c|c|c|}
\hline \multicolumn{5}{|c|}{ Неформальна освіта } \\
\hline \multirow{2}{*}{ 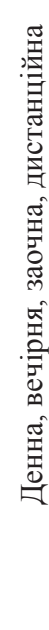 } & $\begin{array}{l}\text { участь у семінарах, практикумах, тренінгах, } \\
\text { вебінарах, майстер-класах відповідно до річ- } \\
\text { ного плану закладу освіти }\end{array}$ & $\begin{array}{l}\text { визначає суб’єкт } \\
\text { освітньої діяльності }\end{array}$ & \multirow{2}{*}{ 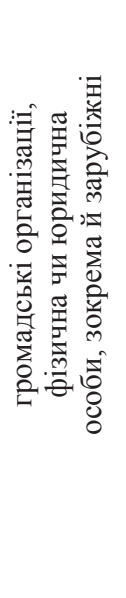 } & $\begin{array}{l}\text { рішенням } \\
\text { педагогічної ради }\end{array}$ \\
\hline & участь у програмах академічної мобільності & $\begin{array}{l}\text { визначає суб’єкт } \\
\text { освітньої діяльності }\end{array}$ & & $\begin{array}{l}\text { рішенням } \\
\text { педагогічної ради } \\
\text { відповідно до постано- } \\
\text { ви Кабінету Міністрів } \\
\text { України «Про порядок } \\
\text { реалізації права на } \\
\text { академічну } \\
\text { мобільність» від } \\
12 \text { серпня } 2015 \text { р. }\end{array}$ \\
\hline \multicolumn{5}{|c|}{ Інформальна освіта } \\
\hline 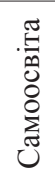 & & $\begin{array}{l}\text { рішенням педагогічної } \\
\text { ради на основі звіту } \\
\text { вчителя }\end{array}$ & 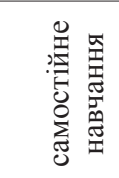 & $\begin{array}{l}\text { рішенням педагогічної } \\
\text { ради }\end{array}$ \\
\hline
\end{tabular}

Висновки. Таким чином, за результатами аналізу сучасних нормативно-правових документів нами виокремлено організаційні засади підвищення кваліфікації педагогічних працівників закладів загальної середньої освіти. Відповідно до загальної мети і завдань нашого дослідження запропоновано систему дій щодо організації ПКПП у закладі загальної середньої освіти. Суть управлінського циклу цього процесу виявляється, по-перше, у рефлексії педагогом особистого рівня професійного розвитку, виборі суб'єкта, освітньої програми, форми і виду підвищення кваліфікації, а по-друге, в адмініструванні изього проиесу, складанні й затвердженні плану, розробиі інструментарію (наказів, положень, розпоряджень тощо) $і$ визнанні результатів ПКПП.

Перспективи подальших досліджень убачаємо в аналізі особливостей мотивації самоаналізу і самовизначення у сфері професійного розвитку, а також інструментарію управління процесом підвищення кваліфікації в сучасних умовах становлення автономії закладу освіти, особливостей фінансування і оплати послуг в умовах децентралізованого автономного управління закладом освіти тощо.

\section{СПИСОК ВИКОРИСТАНОЇ ЛІТЕРАТУРИ}

Про освіту: Закон України від 05.09.2017 р. №2145VIII. Відомості Верховної ради. 2017. № 38-39. С. 380. URL: https://zakon 2/rada/gov.ua/law/show 2145-19/ (дата звернення: 10.07.2021).

Про повну загальну середню освіту: Закон України. Відомості Верховної ради. 2020. №31. С. 226. URL: https://zakon.rada.gov.ua/laws/show/463-20\#Text (дата звернення: 16.07.2021).
Порядок підвищення кваліфікації педагогічних та науково-педагогічних працівників: постанова КМУ від 21.08.2019 р. № 800. URL: https:// zakon.rada.gov. ua/laws/show/800-2019-п. (дата звернення: 22.07.2021).

Олійник, В. В. (2013). Тенденції розвитку післядипломної педагогічної освіти в умовах трансформації суспільства. Проблеми розвитку педагогічної освіти. №1. C. 56-66. URL: https:// Repositor. Kpi.kharkov.ua. Kh.piPress/1664/TPUSS 2013 1 (дата звернення: 10.07.2021).

Мірошник, $\overline{\mathrm{C}}$. I. (2016). Професійний розвиток педагога: сучасні підходи. Народна освіта: електронне наукове фахове видання. Вип. №2 (29). С.13-18. URL: https://narodnaosvita.kiev.ua/ page_id=4133 (дата звернення: 11.07.2021).

Оліфіра, Л. М. (2017). Диверсифікація неперервного підвищення кваліфікації керівних і педагогічних кадрів освіти: європейський досвід і вітчизняні перспективи. Післядипломна освіта в Україні. № 1. С.102-105.

Лунячек, В. Е. Підвищення кваліфікації педагогічних працівників: тенденції в умовах глобалізації. URL: https://jornals.edu.ua./index.php/sciencemtans/article/ view/702/827 (дата звернення: 10.07.2021).

Воротнікова, І. П. (2018). Моделі професійного розвитку вчителя в умовах реформи післядипломної педагогічної освіти. Неперервна професійна освіта: теорія і практика. Вип. 3-4. С. 21-27. URL: https:// nbuv.gov.ua/UJRN/NPO_2018_3-4_5 (дата звернення: 20.07.2021).

Осадчий, І. Г. (2016). Організаційно-методичні засади підвищення кваліфікації педагогічних працівників за сертифікованою пролонгованою формою навчання. Народна освіта: електронне наукове фахове видання. Вип. № 3 (30). С. 4. URL:https://narodnaosvita.kiev.ua/ page_id=4291 (дата звернення: 10.07.2021). 


\section{REFERENCES}

Pro osvitu: Zakon Ukrainy vid 05.09.2017 r. №2145VIII [On Education: Law of Ukraine of 05.09.2017 №2145VIII].Vidomosti Verkhovnoi rady. 2017. № 38-39. S. 380. URL: https:// zakon 2/rada/gov.ua/law/show 2145-19/ (data zvernennia: 10.07.2021). [in Ukrainian].

Pro povnu zahalnu seredniu osvitu: Zakon Ukrainy [On complete general secondary education: Law of Ukraine ]. (2020). Vidomosti Verkhovnoi rady. № 31. S. 226. URL: https://zakon.rada.gov.ua/laws/show/463-20\#Text (data zvernennia: 16.07.2021). [in Ukrainian].

Poriadok pidvyshchennia kvalifikatsii pedahohichnykh ta naukovo-pedahohichnykh pratsivnykiv: postanova KMU vid 21.08. 2019 r. № 800 [The order of advanced training of pedagogical and scientific-pedagogical workers: resolution of the Cabinet of Ministers of 21.08.2019 № 800]. URL: https:// zakon.rada.gov.ua/laws/show/800-2019-p. (data zvernennia: 22.07.2021). [in Ukrainian].

Oliinyk, V. V. (2013). Tendentsii rozvytku pisliadyplomnoi pedahohichnoi osvity $\mathrm{v}$ umovakh transformatsii suspilstva [Trends in the development of postgraduate pedagogical education in the conditions of society transformation]. Problemy rozvytku pedahohichnoi osvity. № 1. S. 56-66. URL: https:// Repositor. Kpi.kharkov. ua. Kh.pi-Press/1664/TPUSS_2013_1 (data zvernennia: 10.07.2021). [in Ukrainian].

Miroshnyk, S. I. (2016). Profesiinyi rozvytok pedahoha: suchasni pidkhody [Professional development of a teacher: modern approaches]. Narodna osvita: elektronne naukove fakhove vydannia. Vyp. № 2 (29). S.13-18. URL: https://narodnaosvita.kiev.ua/ page_id=4133 (data zvernen- nia: 11.07.2021). [in Ukrainian].

Olifira, L. M. (2017). Dyversyfikatsiia neperervnoho pidvyshchennia kvalifikatsii kerivnykh i pedahohichnykh kadriv osvity: yevropeiskyi dosvid i vitchyzniani perspektyvy [Diversification of continuous professional development of management and pedagogical staff of education: European experience and domestic prospects]. Pisliadyplomna osvita v Ukraini. № 1. S.102-105. [in Ukrainian].

Luniachek, V. E. Pidvyshchennia kvalifikatsii pedahohichnykh pratsivnykiv: tendentsii v umovakh hlobalizatsii. [Professional development of teachers: trends in globalization]. URL: https://jornals.edu.ua./index.php/sciencemtans/ article/view/702/827 (data zvernennia: 10.07.2021). [in Ukrainian].

Vorotnikova, I. P. (2018). Modeli profesiinoho rozvytku vchytelia v umovakh reformy pisliadyplomnoi pedahohichnoi osvity [Models of professional development of a teacher in the conditions of reform of postgraduate pedagogical education]. Neperervna profesiina osvita: teoriia i praktyka. Vyp. 3-4. S. 21-27. URL: https://nbuv.gov.ua/UJRN/NPO_2018_3-4_5 (data zvernennia: 20.07.2021). [in Ukrainian].

Osadchyi, I. H. (2016). Orhanizatsiino-metodychni zasady pidvyshchennia kvalifikatsii pedahohichnykh pratsivnykiv za sertyfikovanoiu prolonhovanoiu formoiu navchannia [Organizational and methodological bases of advanced training of pedagogical workers according to the certified prolonged form of education]. Narodna osvita: elektronne naukove fakhove vydannia. Vyp. № 3 (30). S. 4. URL: https://narodnaosvita.kiev.ua/ page id $=4291$ (data zvernennia: 10.07.2021). [in Ukrainian].

Дата надходження до редакиіï: 06.08.2021 p. 